\title{
Migrant Labour Movement across West African Borders: Character, Trends and Implication on Mediterranean Crossings
}

Dr. Aliyu A. Kware*, Dr. Sama'ila Abubakar

Department of History Usmanu Danfodiyo University P.M.B: 2346, Sokoto, Nigeria

DOI: $10.36347 /$ sjahss.2020.v08i04.010

| Received: 12.04.2020 | Accepted: 20.04.2020 | Published: 30.04.2020

*Corresponding author: Dr. Aliyu A. Kware

Abstract

Migration is a fundamental part of the people's history. It has consistently continued shaping identity of people and therefore one of the most powerful defining forces of West Africa. Nigeria was a net recipient of migrants especially from Niger, Ghana, Benin, Mali and other West African countries. Immigrants flooding Nigeria were from different social and economic backgrounds and drawn to the country for the socio-economic opportunities. The changing trend in the economy of the region in the 1980s however, changed the whole situation. Most of the migrants began to use Nigeria as a transit destination towards Europe through North Africa. In spite of stricter immigration policies and global awareness of the dangers inherent in illegal routes to the destinations of the migrants, there seems to be increase in such migrations. Of all the routes, the most reported and most dangerous has been the Mediterranean route, which is popularly used by African migrants aiming to migrate to Europe for greener pastures. Since the 2000s, troubling number of deaths of African migrants aiming to cross to Europe is recorded on the journey, either on the Saharan Desert or the Mediterranean Sea. United Nations for instance reported that an estimated 33,761 died or were declared missing on the route between 2000 and 2017. The focus of this paper is to look at the inter-play of factors influencing labour movement across West Africa's international borders and its implication on migration along Mediterranean routes. It would show that although states policies for the control of illegal migration in the region may have immediate impact on the internal dimension of labour movement, the special characteristics of African border areas always make such impact very limited.

Keywords: Colonialism, Labour, Mediterranean, Migration, Poverty, West Africa.

Copyright @ 2020: This is an open-access article distributed under the terms of the Creative Commons Attribution license which permits unrestricted use, distribution, and reproduction in any medium for non-commercial use (NonCommercial, or CC-BY-NC) provided the original author and source are credited.

\section{INTRODUCTION}

There has been the general belief that migration across the Mediterranean is a new phenomenon and that the area has been historically "divided", with people moving from the poor southern shores to those of the prosperous north [1]. Thus, Africa is often seen as a continent of mass displacement and migration caused by poverty and violent conflicts. Such view has been amplified by researchers and media practitioners in recent years, that irregular migration from Africa to Europe across Mediterranean is SouthNorth exodus. Sensationalist media reportage and popular discourses give rise to an image of an 'exodus' of desperate Africans fleeing poverty at home in search of the European 'El Dorado' (Adeniyi, xxii). Not only media and politicians, but also scholars fuel the image of a rising tide of poverty-driven African emigration. This reflects a broader tendency in the research literature to cast 'South-North' migration as a symptom of development failure [2]. Based on the common perception that poverty and income gaps between poor and rich countries are the 'root causes' of migration, and faced with the ineffectiveness and perverse effects of increased border controls, the frequently proposed long-term 'solution' to this phenomenon is to stimulate development in origin countries through aid, trade, or remittances.

This assumption has ignored one major fact about the area: that migration is central to the history of the Mediterranean and there is a rich tradition of contact between its two shores [1]. In the early modern period it was mostly people from Europe who went to Africa and the Middle East in search of a better life or to escape religious persecutions. Many of those who crossed the Mediterranean in the early modern era did so against their will, fleeing wars, or political or religious persecutions. The Mediterranean Sea is one of the great centres of civilization. As a most dynamic place of interaction between societies, its significant role in 
shaping world history will never be over emphasized. In its long history therefore, human diversity, change and tension as well as the current crisis in most of the countries in Africa-leading to human movement in large number across the Mediterranean basin make it another chapter in the history of migration in West Africa.

The ancient slave trade routes that crossed the area since antiquity granted the arrival of African slaves to Europe and Ottoman territories. Furthermore, people also travelled across the Mediterranean out of their own choice. The area has always been characterized by a constant movement of soldiers, pilgrims, diplomats and travellers. Like today, men and women moved in search of a better life. But in the early modern period this movement was mostly directed from the northern to the southern shores of the Mediterranean. Regulations regarding the arrival of foreigners, border controls and policies of acceptance varied greatly across the Mediterranean in the early modern period. Authorities often showed a very practical approach. The Ottoman state welcomed Jewish refugees in the 15th and 16th centuries in order to take advantage of their technical competencies and trade networks. This old pattern of migration has given way to the current wave of migration to Mediterranean in form of forced displacement that is related to human trafficking. The trend began to change in the 20th century, when it began to shift in the other direction. The first flow of impoverished peasants from North Africa to Europe, displaced by European colonization, was followed after the wave of post-World War II independence by the return of those Europeans who had settled in colonies [3]. Later, in the 1970s, the arrival of workers from the southern shore of the Mediterranean was encouraged by European governments in need of workers. The roots for this shift in direction of migratory flows were found in economic and political processes that started back in the 17th century, such as the growing influence of European powers [3]. All this shows that the direction of migration is not immutable, it is influenced instead by historical circumstances.

The recent years have however, been marked by a number of serious incidents where boats capsized and sank tragically, claiming the lives of hundreds of so-called boat migrants. According to United Nations estimate about 33,761 died or were declared missing on the route between 2000 and 2017 [4]. United Nations statistics indicate that substantial percentage of the victims was from West African region. What constitutes the main reasons for such influx of people across borders is attributed to unemployment, poverty, institutional weaknesses and fundamentally, the nature of West African borders which remain more or less porous because of its artificial nature [5]. The focus of this paper is to look at the inter-play of factors influencing labour movement across West Africa's international borders and its implication on migration along Mediterranean routes.
Colonial Boundaries and Labour Movement in West Africa

Colonial partition of Africa disrupted the precolonial patterns of relations because it institutionalized certain policies that changed the direction of the trade routes. The colonial partition in the late $19^{\text {th }}$ century has divided the same communities from one another [6]. The consequence of this was that the patterns of ethnic, linguistic, religious, cultural and commercial affinities, which for centuries cut across mere administrative boundaries in Africa, were suddenly and rudely terminated in order to accommodate imperial desires and norms. The mentality, outlook and life prospects of these societies divided by the artificial boundary began to clearly reflect their respective colonial heritage. The allegiance to external languages felt more seriously among the populations of the border regions with culturally coherent territories and where people of different cultural identities have had to be split into two or more units, each faction being placed in the area of jurisdiction of a distinct state which functions to integrate such a part of a pre-existing culture area into a new socio-economic system removed from the original cultural whole [7]. In fact, even when colonial officials later served as members of Boundary Commissions employed to carry out the more serious and painstaking business of demarcation, with a demand for a thorough assessment of the human and geographic realities on ground, the ultimate emphasis on self-interest of the negotiating European powers generally resulted in boundaries that were glaringly disrespectful of the local realities of human settlement pattern and the natural environment [5]. In spite of the indisputable fact of their artificiality and arbitrariness, the boundaries have had to be accepted as legal alignments of the territorial framework of the post-colonial nation-states [4].

Based on this framework it is clear that the nature of African colonial boundaries clearly depicts what Strassoldo calls 'alienated borderlands', which are relatively of recent origin [8]. Most of these states have the paramount problems of internal integration, which also means hardening of the boundaries. At this stage the national states tend to guard their boundaries jealously vis-à-vis neighbouring states to ensure necessary differentiation from the outside. On the one hand, Africans reacted to artificial borders by continuing with their old tradition of inter-community trade, which predates existing borders [9]. Immediately after independence, Africans began to see colonial boundaries as a mere ditch that cannot prevent them from their normal activities hence the development of cross-border trade. Consequently, after independence attempt to enforce restrictions and certain formalities for the movement of people across borders met with serious difficulties.

In the case of Nigeria and her neighbours, the changing economic fortunes have attracted notable mobility in the direction of economically buoyant countries. Nigeria and all the countries sharing border 
with her with the exception of Cameroun are all members of the Economic Community of West African Countries [24]; in which case, the citizens of these countries are to enjoy freedom of movement. However, the changing trend in the economy of the region in the 1980s however, changed the whole situation. Most of the migrants began to use Nigeria and Niger Republic (whose boundaries appear to be very porous owing to their ethnic and historical linkages) as a transit destination towards Europe through North Africa. Bordered by Libya to the northeast, Chad to the east, Nigeria and Benin Republic to the south, and Algeria to the northwest, Niger Republic covers a land area of almost 1,270, 000 kilometres, making it geographically the largest country in West Africa. Over 80 per cent of its land area lies in the Sahara Desert.

Besides being a major source of migrants to neighbouring countries and Europe, Niger is the most popular transit point for West Africans attempting to cross the Sahara desert to Libya and from there to Europe. International Organization for Migration (IOM) study, observed that between February and October 2016, over 300,000 persons left Niger towards Libya and Algeria, most of them originating from Senegal, Nigeria, the Gambia, Mali and other West African countries. ECOWAS countries enjoy freedom of movement through Niger, thus leaving the Nigerien authorities powerless to return migrants from within the Sub-region attempting to cross illegally into Libya. Some non ECOWAS countries also have a bi-lateral agreement with Niger, which guarantee their citizens free movement through the country. These patterns have become so integral to communities along these transit migratory routes that become based on providing services to migrants passing through (http://www.iom.int./countries/niger). In spite of stricter immigration policies by Nigeria on the illegal routes to the destinations of the migrants, there seemed to be increase in such migrations. In the next section attempt is made to look at the factors responsible for migration of labour force in West African region with special focus on Nigeria.

\section{Migrant Labour Movement across West African Borders: The Case of Nigeria}

Like in other parts of Africa, there is evidence of a considerable degree of pre- colonial mobility in West Africa. Throughout known history, there has been intensive population mobility between both sides of the Sahara through the trans-Saharan (caravan) trade, conquest, pilgrimage, and religious education [10]. The trans-Saharan trade connected North and West Africa economically, politically, religiously and socially [11]. It was only with the advent of colonialism, which drew borders where there had been none and created modern states, that trans-Saharan mobility and trade collapsed. With independence, the trend keeps on changing owing to the political and economic changes the region have undergone. These changes were part of the general processes that modified the structure of migration in
West Africa with Nigeria as a centre of attraction to the migrants.

Nigeria which is the most populous country in West Africa in terms of population and industrial outputs, according to 2015 data, accounts for 15.15 and 51.66 per cent of the total population of Africa and the entire Economic Community of West African States (ECOWAS), sub-region, respectively. Its annual population growth rate is relatively high, and estimated to be between 2.4 and 2.8 per cent respectively in the 1991 and 2006 censuses. Also, the country has a youthful population, with 43 per cent of its total population being under 15 years old and with a low percentage of 3 per cent for those 65 years and above [9]. Migration being a selective phenomenon, particularly, in favour of the active and young, the youthful nature of the Nigerian population, therefore, creates a large reservoir of potential migrants who have high propensity for internal and international migration.

In fact, as pointed out by Olukoshi [12], the period since the beginning of the 1980s, has been marked by steadily deepening economic crisis which has had far reaching consequences for various sectors of the Nigerian economy. Prior to the crisis, the Nigerian economy enjoyed almost a decade of unprecedented revenue boom arising from the petroleum price increases of the 1970s [13]. With output of around two million barrels a day, the country is the leading producer in Africa, the sixth-largest within the Petroleum Exporting Countries (OPEC) and the tenth largest in the World [12]. During the period, Nigeria enjoyed economic boom evident by growing industrial sector and output, rising per capital national income, a respectable payment position and increased inflow of foreign investments, among other indicators. This ultimately has attracted large labour force from the neighbouring countries in search of greener pasture. However, by the early 1980s, the Nigerian economic boom came to a halt by a deepening economic crisis which has rapidly engulfed its manufacturing industry among several other sectors of the economy. The crisis has resulted into the adoption by the Nigerian state of structural adjustment programme sponsored by the International Monetary Fund and the World Bank[25]. Since its creation, far from providing solutions, it has become part and parcel of the dynamics of the country's economic crisis, exacerbating existing pre-adjustment problems. The impact of Structural Adjustment Programme (SAP) is felt more on the industrial sector, which has both forward and backward linkages with other sectors of the economy. Towards the end of the 1980s, it became obvious that the ambitious public sector efforts in various industrial sectors were not making the desired development impact. Consequently, the country has to take drastic measures to revamp the economy. Among these measures was the review of its immigration policies, by cracking down on illegal migrant workers in the 1980s [9]. It would be recalled that, the immigration of ECOWAS citizens into Nigeria 
became momentous after the Protocol on Free Movement of Goods, Capital and People was ratified in 1980 [14]. This almost coincided with the period of economic buoyancy in Nigeria, such that many ECOWAS citizens immigrated into Nigeria. But this was short lived due to a sharp decline in the price of oil. Consequently, in January/February 1983 and April/June 1985, many ECOWAS citizens that had exceeded the 90 days of grace without the residence permit were expelled from the country.

In addition, by the late 1980s, some other changes in the economic and political policies of the country resulted in changes in the pattern of migration into Nigeria. One in particular is the adoption of the Structural Adjustment Programme (SAP) in June 1986. SAP dictated a shift from the official policy of full employment to substantially reduced government spending on critical services, such as health, education and housing [15]. This created a greater tendency for persons to emigrate. Evidence included the relatively large number of women traders that shuttled between Lagos and Abidjan in Cote d'Ivoire and in a few other coastal West African countries [14]. Furthermore, between 1983 and 1985, Nigeria followed the Ghanaian example and expelled an estimated two million low skilled African immigrants, including over one million Ghanaians [16]. Since year 2000 however, there were changes in the pattern of internal migration in West Africa. It appears that the regional orientation and movement of emigrants are now directed mainly to transit countries. Most of these migrants that moved to transit countries targeted either Europe or some Asian countries as shown in the table below;

Table-1: Estimates of Emigrants Population in Some Countries of West Africa from Year 2000

\begin{tabular}{|l|l|c|l|}
\hline Countries & Population & Emigrant stock & \% of Population \\
\hline Burkina Faso & $11,292,000$ & $1,121,758$ & 9.93 \\
\hline Cameroon & $14,856,000$ & 231,169 & 1.56 \\
\hline Cote d'voire & $16,735,000$ & 151,755 & 0.91 \\
\hline Ghana & $19,867,000$ & 906,698 & 4.56 \\
\hline Mali & $11,647,000$ & $1,213,042$ & 10.42 \\
\hline Niger & $11,782,000$ & 437,844 & 3.72 \\
\hline Nigeria & $\mathbf{1 1 7 , 6 0 8 , 0 0 0}$ & $\mathbf{8 3 6 , 8 3 2}$ & $\mathbf{0 . 7 9}$ \\
\hline Senegal & $10,343,000$ & 463,403 & 4.48 \\
\hline
\end{tabular}

Source: Extracted from Bilateral Migration Matrix, downloaded from www.worldbank.org/prospects/migrationand remittances, accessed, 23/04/2019

The data on the above table seems to exemplify the varied migration patterns in West Africa. Some selected countries in West Africa such as Burkina Faso, Cameroon, Cote' d'voire, Ghana, Mali, Niger, Nigeria and Senegal have the highest estimated emigrant stock. The data is derived from the World Bank statistics indicating that, Mali and Burkina Faso have the highest percentage of immigrants with 10.42 and 9.93 per cent of their total population respectively. It should however, be noted that Nigeria, Ghana and Cote d'voire are the largest emigrants recipient countries in the region. The informal nature of the migration tends to make it difficult to see the picture clearly.

Currently, within the context of ECOWAS Protocol on Free Movement of Persons, Rights of Residence and Establishment, most countries of the sub-region have enacted, or retained a series of laws, which in effect restrict 'foreigners', including nationals of ECOWAS, from participating in certain kinds of economic activities; the expulsion of aliens also negated the raison d'être for establishing the Community. So long as the economies of recipient countries accommodated clandestine labour migrants there was little sign of stress. As economic conditions worsened and unemployment among nationals deepened, immigrants become targets for reprisals through expulsion [17]. It should be emphasized that Illegal immigrants were being expelled from virtually all West African countries before and even after the formation of ECOWAS. Before the year 2000, the orientation of emigrants in West Africa was internal. However, by 2000, substantial percentage of emigrants tended to migrate outside the region but used some countries as transit for en route towards North Africa and Europe. The regional orientation of these migrants is shown in the table below;

Table-2: Estimates of Destination of Emigrant Population from Some Selected West African Countries

\begin{tabular}{|l|l|}
\hline Emigrant Countries & Percentage of emigrants to West Africa \\
\hline Burkina Faso & 90.1 \\
\hline Cameroon & 9.7 \\
\hline Cote d'Voire & 35.9 \\
\hline Ghana & 66.4 \\
\hline Mali & 82.7 \\
\hline Niger & 29.0 \\
\hline Nigeria & $\mathbf{1 4 . 1}$ \\
\hline Senegal & 39.3 \\
\hline
\end{tabular}

Source: Extracted from Bilateral Migration Matrix, downloaded from www.worldbank.org/prospects/migrationandremittances, accessed on $23 / 04 / 2019$ 
What appears from the table above indicates the overriding regional orientation of West Africa internal migration. The table indicates that substantial percentage of these emigrants moved towards West Africa. Burkina Faso and Mali have the highest percentage while Nigeria, Niger and Cameroon have the lowest percentage of internally emigrants' population. This also indicates that intra-regional migration remains far more important than migration to the rest of the World. However, for those countries that served as transit migration states to other parts of the World, the statistics of emigrants remain very significant. Most of these emigrants used these states as a stepping stones before sneaking to other parts of the World mainly by using various strategies across the Mediterranean Sea as discussed in the next section.

\section{Migration across Mediterranean: Nature, Pattern and Trends}

As we highlighted in the last section with reference to Nigeria, the political and economic crises that engulfed a number of countries in West Africa in the 1980s, affected the wave and pattern of migration in the sub-region. The civil wars in Sierra Leon (19912001), Liberia (1989-1996 and 1999-2003), Guinea (1999 -2000) and Cote' d'Ivore since 2002, led to the loss of over a quarter million lives and the concentration of a population of over 1.1 million refugees and internally displaced persons in the subregion [18]. The crisis in Cote d'Ivore significantly affected the pattern of migration in the sub-region, as hundreds of thousands of migrants from Burkina Faso flee the country. The crisis in the late 1980's and early 1990s in West Africa prompted the diversification of destination, which coincided with two migration poles at northern and southern extremes of the continent, that is pan-African Libya and post-apartheid south Africa $[18,26]$.

Since the 1990s, there have been significant increase and in the configuration of migrants from the region to Europe and North America, from countries such as Nigeria, Senegal, and Ghana. This comprised skilled professionals in the areas of medical health and irregular migrants who tended to work in the informal service sector, construction and agriculture, while some were self-employed entrepreneurs. Official figures showed that 351,000 West Africans lived in the US, 41,000 in Canada, 280,000 in France, 176,000 in the UK, 82,000 in Italy and 68,000 in Portugal [19]. Nigerians $(135,000)$ were the dominant people of West African origin, followed by Ghanians (66, 0000 and Liberians $(39,000)$ [20]. Nigeria, Senegal, Ghana, Cape Verde, Mali, and Cote d'Ivore account for a greater percentage of migrants of West African origin found in EU countries, and migration to Italy, Spain and Portugal from the region is on the high [21].

This picture drastically changed in the 1990s. A progressive change in Libya's foreign policy contributed to a major surge in trans-Saharan migration to Libya. In particular, the 1992-2000 UN embargoes prompted Libya to intensify its relations with subSaharan countries. As part of these renewed "panAfrican" policies, Libya started to welcome subSaharan Africans to work in Libya. Traditionally a destination for migrants from Arab North African countries including Sudan, Libya became a major destination for migrants from West Africa and the Horn of Africa [2]. In the early 1990s, most migrants came from Libya's neighbours Sudan, Chad, and Niger, which subsequently developed into transit countries for migrants from a much wider array of sub-Saharan countries thereby reducing the pressure on Nigeria which had been the economic engine of the region (Ibid).

Furthermore, as study by Afolayan et-al. [14] has shown, at the initial stage, most West Africans made the trans-Saharan crossing in order to work in Libya. The presence of sub-Saharan migrants in Morocco and Tunisia remained largely limited to relatively smaller numbers of students, traders, professional workers, and some refugees from the Democratic Republic of Congo, Liberia, and Sierra Leone. However, it was particularly since the late 1990 s that Algeria, Morocco and Tunisia started witnessing an increase in migration from an increasingly diverse array of sub- Saharan countries. These changes in migration patterns have probably been reinforced under the influence of mounting xenophobia in Libya after the violent clashes between Libyans and African workers in 2000. This has presumably contributed to a diversification and partial westward shift of transSaharan migration routes towards Algeria, Morocco and Tunisia. Nevertheless, migration to Libya continued because of the persistent need for immigrant labour, although this migration has become increasingly irregular as a consequence of its restrictive immigration regime.

Around 2000, the next fundamental shift in migration patterns occurred when sub-Saharan migrants started to join Maghrebians in their attempts to enter the Spanish enclaves of Ceuta and Melilla illegally or to cross the Strait of Gibraltar to Spain or from Tunisia to Italy (Lampedusa, Pantalleria, or Sicily) by pateras (fisher boats). Maghrebians had started doing so since Italy and Spain introduced visa requirements for North African workers in the early 1990s. In addition, subSaharan migrants in Libya have increasingly tried to cross to Europe directly from the Libyan coast, transforming Libya from a destination country into a destination and transit country. In this way, sub-Saharan migrants forged a vital connection between the resurgent trans-Saharan and the already established Euro-Mediterranean migration systems [2]. The increasing presence of West Africans in the Maghreb, the persistent demand for migrant labour in (southern) Europe, where salaries and living conditions are much 
better than in Libya, and the already well-established networks of smugglers helping Maghrebians to cross the Mediterranean all contributed to this fundamental shift in the African-European migration landscape. However, it was not until Libyan crisis of 2011 that some West African migrants already residing in Libya started looking for ways to sneak across Mediterranean in search of greener pasture in Europe. The Libyan crisis which ousted Muammar Gaddafi from power in 2011 led to the dispersal of population most of whom moved to other parts of Mediterranean areas towards Europe.

Migrants used numerous land, sea, and air routes to reach their desired destinations in North Africa and Europe. Europe's increasingly restrictive immigration policies and intensified migration controls have led to a growing reliance on overland routes, although migrants who could afford it made at least part of the journey to North Africa by air. The trans-Saharan journey was generally made in several stages, and might take anywhere between one month and several years. On their way, migrants often settled temporarily in towns located on migration hubs to work and save enough money for their onward journeys, usually in large trucks or pick-up vans. Although a multitude of trans-Saharan routes existed, at least until recently, the majority of overland migrants entered the Maghreb from Agadez in Niger Republic [9]. Agadez is located on a historic crossroads of trade routes that now extend deep into West and Central Africa. From Agadez, migration routes bifurcated to the Sebha oasis in Libya and to Tamanrasset in southern Algeria. From southern Libya, migrants moved to Tripoli and other coastal cities or to Tunisia; from the coast, migrants traveled by boats to either Malta or the Italian islands of Lampedusa, Pantalleria, and Sicily [9]. Furthermore, from Tamanrasset in Algeria, migrants moved to the northern cities or entered Morocco via the border near Oujda. From Oujda in Morocco, migrants either entered the EU by crossing the sea from the north coast or entered the Spanish enclaves of Ceuta or Melilla or moved to Rabat and Casablanca, where they settled down at least temporarily. Since 1999, tougher policing at the Strait of Gibraltar has led to a general diversification in attempted crossing points. Migrants started crossing the Mediterranean Sea from more eastern places on the Moroccan coast or Algeria to mainland Spain, from the Tunisian coast to the Italian islands, and from Libya to Italy and Malta. Since 2001 migrants in Morocco have increasingly moved southward to the Western Sahara in order to get to the Canary Islands, a Spanish territory in the Atlantic Ocean [9]. On the western edge of the continent, and in a likely response to increased border controls and internal policing in the Mediterranean and North Africa, there has been a recent increase in migrants avoiding the trans-Saharan crossing to the Maghreb altogether by sailing directly from the Mauritanian, Cape Verdean, Senegalese and other West African coasts to the Canary
Islands on traditional wooden fishing canoes [22]. The journeys through all the above routes have never been easy but difficult, risky and very dangerous. Thousands of lives have been lost as a result of that. Instead of escaping poverty, lives have been wasted.

\section{CONCLUSION}

The dynamics of migration across West African borders has demonstrated the changing and extremely complex nature of the phenomenon over the recent past. These manifest in the changes in the region's economy which determines changes in the increasing volume, migration streams as well as the changing causes of migration. Our concluding remark shares Da Hass [23] views that see a clear relation between levels of socio-economic development and the volume and geographical orientation of African emigration. More marginal, poorer or landlocked countries tend to have lower absolute and relative levels of extra-continental migration, and their migration is primarily directed towards other African countries. This seems to confirm migration transition theory, according to which materially poor populations of the least developed countries have fewer capabilities to move, and when they move, they tend to move over shorter distances, either internally, or to other African countries. Therefore, the major determinants of emigration in most West African countries are the existing high level of unemployment, poverty, internal conflict, poor management of the economy, dearth of socio-economic infrastructure in rural areas and poor governance. Since the migration trend in the region reflect internal dimension, it is very difficult to see clear statistics of emigrants crossing to other states in the region. It is however, easy to see the changes in the migration trend to other parts of the World. The dynamics of regional migration reflects the factors responsible for the shift in diversification of migration destinations from hitherto traditional destinations in West Africa to Western Europe and Middle East. What are the consequences of this phenomenon to the region? The loss of the active labour force and highly skilled professionals from areas of origin tend to create empty spaces in the development equation and space in West Africa. For effective implementation of migration policies, there should be capacity building of the actors and development of infrastructure. Currently, the enforcement agencies, such as, the immigration and custom services, lack the necessary capacity in several areas of migration measures and controls. There is therefore the need for retraining of the work force on sustained basis in order to be abreast with immigration and emigration issues and challenges. Development of capacity in the Information and Communication Technology (ICT) for migration agencies and operators has become mandatory for effective management. Regional networking of emigration and immigration information should be put in place. Above all poverty and inequality in Africa particularly in West African sub region should be reduced to the minute minimum so 
that the citizens do not see any reason for them to emigrate and cross dangerous terrains for livelihood.

\section{REFERENCES}

1. Stokholm T. The Mediterranean Migrant Crisis: A Critical Challenge to Global Nation-States. Working Paper, University of East London, Centre for Social Justice and Change, London; 2016.

2. Flahaux ML, De Haas H. African migration: trends, patterns, drivers. Comparative Migration Studies. 2016; 4: 1.

3. Amin S, editor. Modern migrations in western Africa. Routledge; 2018 Aug 16.

4. African Union Border Programme. AUBP, From Barriers to Bridges: Collection of Official Texts on African Borders from 1963 to 2012, Addis Ababa; 2013.

5. Ashafa AM. 'Introduction', in Ashafa A.M, M.T. Usman and A. Sama'ila, (eds.), Readings in PostColonial Borders and Economy in West Africa, Pyla-Mak, Kaduna; 2018.

6. Miles WFS. Scars of Partition: Postcolonial legacies in French and British Borderlands; 2014.

7. Asiwaju AI. West African transformations: Comparative impacts of French and British Colonialism, Lagos; 2001.

8. Strassoldo R. Frontier Regions: An Analytical Study; European Conference of Ministers Responsible for Regional Planning, 2nd Session, la Grande Motte, September 25-27, 1973. Council of Europe; 1973.

9. Lipede A. 'Women Trafficking and Insecurity in West Africa: Character, Trend and Scale in Nigeria', in Barkindo, B.M. and Lipede, A. (eds.), Human Trafficking and Economic Crimes across Nigeria's International Borders, Spectrum, Ibadan; 2007.

10. Hopkins AG. An Economic History of West Africa, London; 1974.

11. Falola T. "Trade and Markets in Pre-colonial Economy", in G.O. Ogunremi and E.K. Faluyi (eds.), An Economic History of West Africa Since 1750, Ibadan, Rex Charles Publication;1996.

12. Olukoshi AO. The policies of Structural Adjustment in Nigeria, Heinemann, London; 1993.

13. Olukoshi AO. West Africa's Political Economy in the Next Millennium: Retrospect and Prospect. CODESRIA, Dakar; 2003.

14. Afolayan AA. Dynamics of International Migration in Nigeria: A review of Literature,
Department of Geography, University of Ibadan, Nigeria; 2008.

15. Ikwuyatun GO. The changing face of migration in West Africa: the case of Nigeria, Department of Geography, University of Ibadan, Nigeria; 2012

16. Gleason HA, Cronquist A. Manual of vascular plants of northeastern United States and adjacent Canada. Bronx, NY: New York Botanical Garden; 1991.

17. Ojo JO. Understanding West African Traditional Religion. SO Popoola Printers; 1999.

18. Adeniyi O. From Ferrying Pan to Fire: How African Migrants Risk Everything in their Futile Search for a Better Life in Europei, Bookcraft, New Bodija, Ibadan; 2019.

19. OECD. International migration outlook. OECD publishing; 2006 Jun 14.

20. Dixon-Woods M, Cavers D, Agarwal S, Annandale E, Arthur A, Harvey J, Hsu R, Katbamna S, Olsen R, Smith L, Riley R. Conducting a critical interpretive synthesis of the literature on access to healthcare by vulnerable groups. BMC medical research methodology. 2006 Dec;6(1):35.

21. Ikwuyatum GO. Migration as a threat to national security: The case of Nigeria in the Boko Haram Era. InAnnual International Conference of the Royal Geographical University of Edinburgh, George Square, Edinburgh EH8 9JU, UK 2012.

22. Choplin JM, Hummel JE. Comparison-induced decoy effects. Memory \& cognition. 2005 Mar 1;33(2):332-43.

23. Wilson, T.M. and Hastings D. Border Identities: Nation and State at International Frontiers, Cambridge; 1998.

24. ECOWAS Commission, Annual report 2008: Forging Regional response to Global Economic and financial Crises, Abuja, Nigeria, 2009

25. International Organization of Migration, 'IOM evacuates more stranded Burkenabe Migrants from Libya; 2018', http://www.iom.int./countries/niger, January

26. United Nations Organizations. "UN reports more than 300 migrant deaths on Mediterranean crossing in first two months of 2017", UN News, Global Perspective on Human;2017. Stories, https://news.un.org/en/story/2017/02/552142-unreports-more-300-migrant-deaths-mediterraneancrossing-first-two-months-2017, accessed, 